\title{
Synergy between roads and disturbance favour Bromus tectorum L. invasion
}

\author{
Karina L Speziale ${ }^{\text {Corresp., }}{ }^{1}$, Agustina di Virgilio ${ }^{1,2}$, Maria N Lescano ${ }^{3}$, Gabriela Pirk ${ }^{3}$, Jorgelina Franzese $^{3}$ \\ ${ }^{1}$ Grupo de Investigaciones en Biología de la Conservación, Departamento de Ecología, Laboratorio Ecotono, INIBIOMA(CONICET-UNCOMA), Bariloche, \\ Argentina \\ 2 Grupo de Ecología Cuantitativa, INIBIOMA, CONICET-UNCOMA, Bariloche, Río Negro, Argentina \\ 3 Departamento de Ecología, Laboratorio Ecotono, INIBIOMA (CONICET-UNCOMA), Bariloche, Argentina \\ Corresponding Author: Karina L Speziale \\ Email address: karina.speziale@comahue-conicet.gob.ar
}

Background. Global change produces pervasive negative impacts on biodiversity worldwide. Land use change and biological invasions are two of the major drivers of global change that often coexist; however, the effects of their interaction on natural habitats have been little investigated. In particular, we aimed to analyse whether the invasion of an introduced grass (Bromus tectorum; cheatgrass) along roads verges and the disturbance level in the natural surrounding habitat interact to influence the degree of $B$. tectorum invasion in the latter habitats in north-western Patagonia. Methods. Along 6 different roads, totalling approximately $370 \mathrm{~km}$, we set two $50 \mathrm{~m} \times 2 \mathrm{~m}$ sampling plots every $5 \mathrm{~km}$ (73 plots in total). One plot was placed parallel to the road (on the roadside) and the other one perpendicular to it, towards the interior of the natural surrounding habitat. In each plot, we estimated the $B$. tectorum plant density in $1 \mathrm{~m}^{2}$ subplots placed every $5 \mathrm{~m}$. In the natural habitat, we registered the vegetation type (grassy steppe, shrub-steppe, shrubland, and wet-meadow) and the disturbance level (low, intermediate, and high). Disturbance level was visually categorized according to different signs of habitat degradation by anthropogenic use. Results. $B$. tectorum density showed an exponential decay from roadsides towards the interior of natural habitats. The degree of $B$. tectorum invasion inside natural habitats was positively related to $B$. tectorum density on roadsides only when the disturbance level was low. Shrub-steppes, grassy steppes and shrublands showed similar mean density of $B$. tectorum. Wet-meadows had the lowest densities of $B$. tectorum. Intermediate and highly disturbed environments presented higher $B$. tectorum density than those areas with low disturbance. Discussion. Our study highlights the importance of the interaction between road verges and disturbance levels on $B$. tectorum invasion in natural habitats surrounding roads of north-western Patagonia, particularly evidencing its significance in the invasion onset. The importance of invasion in road verges depends on disturbance level, with better conserved environments being more resistant to 
invasion at low levels of $B$. tectorum density along road verges, but more susceptible to road verges invasion at higher levels of disturbance. All the habitats except wet-meadows were invaded at a similar degree by $B$. tectorum, which reflects its adaptability to multiple habitat conditions. Overall, our work showed that synergies among global change drivers impact native environments favouring the invasion of $B$. tectorum. 
1 Synergy between roads and disturbance favour Bromus tectorum $\mathrm{L}$. invasion

2 Karina L. Speziale ${ }^{\mathrm{a}}$, Agustina di Virgilio ${ }^{\mathrm{a}, \mathrm{b}}$, María N. Lescano ${ }^{\mathrm{c}}$. Gabriela Pirk ${ }^{\mathrm{c}}$, Jorgelina

3 Franzese $^{c}$.

4 a Grupo de Investigaciones en Biología de la Conservación-Laboratorio Ecotono-INIBIOMA

5 (CONICET-UNCOMA), Quintral 1250 - R 8400 FRF, Bariloche, Argentina,

6 karina.speziale@comahue-conicet.gob.ar.

7 b Grupo de Ecología Cuantitativa, INIBIOMA (CONICET-UNCOMA), Bariloche, Argentina.

$8{ }^{\mathrm{c}}$ Departamento de Ecología, Laboratorio Ecotono-INIBIOMA (CONICET-UNCOMA),

9 Bariloche, Argentina.

11

12

13

\section{Abstract}

Background. Global change produces pervasive negative impacts on biodiversity worldwide. Land use change and biological invasions are two of the major drivers of global change that often coexist; however, the effects of their interaction on natural habitats have been little investigated. In particular, we aimed to analyse whether the invasion of an introduced grass (Bromus tectorum; cheatgrass) along roads verges and the disturbance level in the natural surrounding habitat interact to influence the degree of $B$. tectorum invasion in the latter habitats in north-western Patagonia.

Methods. Along 6 different roads, totalling approximately $370 \mathrm{~km}$, we set two $50 \mathrm{~m}$ x $2 \mathrm{~m}$ sampling plots every $5 \mathrm{~km}$ ( 73 plots in total). One plot was placed parallel to the road (on the roadside) and the other one perpendicular to it, towards the interior of the natural surrounding habitat. In each plot, we estimated the B. tectorum plant density in $1 \mathrm{~m}^{2}$ subplots placed every 5 $\mathrm{m}$. In the natural habitat, we registered the vegetation type (grassy steppe, shrub-steppe, shrubland, and wet-meadow) and the disturbance level (low, intermediate, and high). Disturbance level was visually categorized according to different signs of habitat degradation by anthropogenic use.

Results. B. tectorum density showed an exponential decay from roadsides towards the interior of natural habitats. The degree of $B$. tectorum invasion inside natural habitats was positively related to $B$. tectorum density on roadsides only when the disturbance level was low. Shrub-steppes, grassy steppes and shrublands showed similar mean density of B. tectorum. Wet-meadows had the lowest densities of $B$. tectorum. Intermediate and highly disturbed environments presented higher $B$. tectorum density than those areas with low disturbance. 
37 Discussion. Our study highlights the importance of the interaction between road verges and 38 disturbance levels on B. tectorum invasion in natural habitats surrounding roads of north-western

39 Patagonia, particularly evidencing its significance in the invasion onset. The importance of

40 invasion in road verges depends on disturbance level, with better conserved environments being

41 more resistant to invasion at low levels of $B$. tectorum density along road verges, but more

42 susceptible to road verges invasion at higher levels of disturbance. All the habitats except wet-

43 meadows were invaded at a similar degree by $B$. tectorum, which reflects its adaptability to

44 multiple habitat conditions. Overall, our work showed that synergies among global change

45 drivers impact native environments favouring the invasion of $B$. tectorum.

\section{Introduction}

In the Anthropocene era we are now living, human activities impacting on biodiversity are so widespread that are collectively known as anthropogenic global change (Vitousek et al., 1996; Sala et al., 2000). Global change produces pervasive negative impacts on biodiversity from all Earth's ecosystems as consequences of land use change, biological invasions, climate change, overexploitation and alteration of bio-geo-chemical cycles (Sala et al., 2000). The loss of ecosystem functions and services due to biodiversity changes is producing economic impacts via the reduction of food sources, fuel, structural materials, or by changing community composition and vulnerability to invasion (Chapin III et al., 2000). According to Sala and colleagues (2000) and Vitousek and colleagues (1996) two of the major global change drivers threatening biodiversity are currently land use change (e.g. habitat transformation into roads or grazing by domestic animals) and biological invasions (Vitousek et al., 1996; Dukes \& Mooney, 1999; Sala et al., 2000). Particularly concerning is the simultaneous action of separate processes that have a greater total effect than the sum of individual effects alone i.e., synergy among global change drivers (Dukes \& Mooney, 1999; Brook, Sodhi \& Bradshaw, 2008) which is rarely studied (Didham et al., 2005).

Among land use change drivers, roads are still dominating human movements, carrying along them unwanted biological organisms and favouring their long distance dispersal (Von der Lippe \& Kowarik, 2007; Strano et al., 2018). Roads are a major contributor for the spread of introduced plant species (Forman \& Alexander, 1998; Gelbard \& Belnap, 2003; Ibisch et al., 2016). Habitats adjacent to roads are often more homogeneous than natural or semi-natural habitats, as they are subject to increased disturbance and decreased competition compared to more distant natural habitats (Forman \& Alexander, 1998; Spellerberg, 1998). As a consequence, road verges may sometimes harbor short lived, fast growing species which allocate a large proportion of their 
71 photosynthesis products to seed output (Frenkel, 1977), many of which are introduced species 72 (Gelbard \& Belnap 2003; Trombulak \& Frissell, 2000). The linear arrangement of roads, their maintenance works and ordinary traffic, increase plant species dispersal along roadsides, particularly of introduced species (Forman, 2003; Lembrechts et al., 2016; Dainese et al., 2017; Rew et al., 2018).

Once established in roadside habitats, non-native plant species may spread into surrounding environments (Seipel et al., 2012). For instance, introduced species richness is lower in interior habitats respect to roads in Glacier National Park (Tyser \& Worley, 1992), in California (Frenkel, 1977), and in south-eastern Ohio (Christen \& Matlack, 2009) in USA. Both global change drivers, roads and biological invasions, may in addition combine with other land use change drivers within interior habitats pointing at complex interactions as the mechanism producing ecosystem alterations. Among the ones favouring the spread of introduced species within native communities, grazing by domestic animals, and other disturbances are included, as well as extreme weather conditions due to climate change (Brandt \& Rickard, 1994; Davis, Grime \& Thompson, 2000; Bradley, 2009). Of them, overgrazing often favours the invasion of Eurasian grasses possibly due to their longer co-evolution with ungulate grazers turning these grasses more resistant to trampling and grazing (Mack, 1986; Tyser \& Worley, 1992). These potential interactions and synergies among drivers may be highly important in determining the actual impact on biodiversity but yet, they have been little studied (Didham et al., 2007).

Bromus tectorum L. (cheatgrass-downy brome) is a winter annual grass species of Eurasian origin. It is considered invasive in 11 countries, being USA the one with most records (ISSG 2017). In this country it is commonly found along roads and disturbed areas (Hulbert 1955; Gelbard \& Belnap, 2003). Roads act as corridors, particularly favouring B. tectorum cover along paved roads (Gelbard \& Belnap 2003). Seeds are released within the first weeks after ripening at the end of spring. Long distance dispersal is driven by positive interactions with grazers, which, together with its higher competition efficiency with native perennial grasses favour the invasion process (Hulbert, 1955). Unusual phenotypical plasticity and greater efficiency in water and/or nitrogen use probably enable $B$. tectorum to be more suited to frequent disturbance than native species (Mack \& Pyke, 1983; Rice et al., 1992; Lowe, Lauenroth \& Burke, 2003). However, undisturbed sagebrush habitats for example, are resistant to B. tectorum invasion (Lavin et al., 
101 2013). Thus, the conservation status of each environment may then determine the magnitude of

102 the invasion (Rickard \& Vaughan, 1988; Bradford \& Lauenroth, 2006).

103 B. tectorum has been recently described as an invasive species in Patagonia (Speziale,

104 Lambertucci \& Ezcurra, 2014) and its distribution is increasing since the first record in 1937

105 (Biganzoli, Larsen \& Rolhauser, 2013). Particularly, in north-western Patagonia it is widespread

106 along roads (KS personal observation). Like the USA, north-western Patagonia presents climatic

107 conditions that favours its persistence, with cattle raising areas the most invaded ones (Veblen et

108 al., 1992; Bradford \& Lauenroth, 2006; Speziale, Lambertucci \& Ezcurra, 2014).

109 In this work we sampled B. tectorum along road verges and in their close surrounding

110 environments in north-western Patagonia (Argentina), part of the area where the species is

111 described as invader. The comparison of roadsides and natural habitats enabled us to test the

112 invasion degree in relation to the density of B. tectorum at road verges. Additionally, it also

113 allowed us to understand whether the impact of roads interacts with other land-use changes to

114 determine the invasion degree of surrounding environments. We aimed to analyse whether the

115 density of $B$. tectorum along road verges and the disturbance level in the surrounding natural

116 habitats favour the invasion. We hypothesized that the density of $B$. tectorum on the roadsides

117 together with the level of disturbance within the surrounding landscape influence the density of

118 B. tectorum in this latter habitat. We predict that areas with higher density of B. tectorum on the

119 roadsides will record the highest densities of $B$. tectorum within surrounding environments when

120 disturbance is high.

\section{Materials \& Methods}

123 Study area

124 We conducted our fieldwork on the extra-Andean zones in Argentina within the Patagonian sub-

125 region (Fig. 1). The area is subject to a pronounced environmental gradient (Barros et al., 1983)

126 with four distinct dominant physiognomic units: steppes, shrublands, shrub-steppes and wet-

127 meadows (Fig. 1; Paruelo et al., 1998a). Steppes are dominated by perennial grasses as Poa

128 ligularis, Festuca pallescens, and Pappostipa speciosa. Shrublands are dominated by shrubs as

129 Mulinum spinosum, Schinus patagonica, and Anarthrophyllum rigidum, among others. Shrub- 
130 steppes are composed of perennial grasses and include low to medium height shrubs as $M$.

131 spinosum, A. rigidum, Colliguaja intergerrima, and Adesmia spp. Wet-meadows (mallines) are

132 diverse edaphic communities in humid depressions dominated by Juncus spp, Distichlis spp. and

133 other humid-adapted species. In this region, the southern Andes act as a barrier to the humid

134 westerlies causing a greater amount of precipitation in the Andean Cordillera compared with a

135 few $150 \mathrm{~km}$ to the east (Barros et al., 1983; Jobbágy et al., 1995; Paruelo et al., 1998a,b).

136 Precipitation mainly occurs in autumn, and winter ranging from about $800 \mathrm{~mm} / \mathrm{year}$ in the west

137 to $300 \mathrm{~mm} /$ year to the east of our study area. To the west, the area includes shrublands within

138 Nahuel Huapi National Parks reserve, where lands are privately owned. Within the region

139 tourism, forestry and cattle and sheep rearing are the main economic activities. Among the

140 important disturbances in the area are anthropogenic fires and grazing by introduced animals

141 (Veblen et al., 1992).

142

143 Sampling design

144 We travelled the area along 6 different roads around $130 \mathrm{~km}$ on paved roads and $240 \mathrm{~km}$ on

145 unpaved roads. In each road, we set sampling plots every $5 \mathrm{~km}$, with a total of 73 plots (Fig. 1).

146 Each plot consisted of 2 sub-plots of $50 \mathrm{~m}$ long and $2 \mathrm{~m}$ wide. One sub-plot was placed parallel

147 to the road and the other perpendicular to the centre of the first one, towards the interior of the

148 field; starting by the fencing when present. If not, the sub-plot perpendicular to the road started

149 when a vegetation change was observed from vegetation disturbed by road or road maintenance

150 to more pristine vegetation. In each plot, we located a $1 \mathrm{~m}^{2}$ frame subdivided into a 100-celled -

151 grid every $5 \mathrm{~m}$ and we estimated density in categories by counting the number of $B$. tectorum

152 plants: $0=$ no individuals; $1=$ from 1 to 15 individuals; $2=$ from 16 to 25 individuals; $3=$ from 26 to

15350 individuals; $4=$ from 51 to 75 individuals; $5=$ more than 75 individuals. For statistical analysis

154 (see below), this density level was expressed as the approximate density using the maximum

155 number of individuals plants listed above per $\mathrm{m}^{2}$ (hereafter B. tectorum density). When the

156 species was not present up to the first $50 \mathrm{~m}$ to the interior of the habitat we considered it absent

157 without sampling any further. But when B. tectorum was still present, we kept walking $50 \mathrm{~m}$

158 more to register the maximum distance where $B$. tectorum could be found and assigned a

159 category of density. When we still found B. tectorum beyond those $100 \mathrm{~m}$ we recorded its

160 presence as "more than $100 \mathrm{~m}$ ". This resulted in distances sampled that ranged from 0 to $100 \mathrm{~m}$ 
161 away from roads. Additionally, we registered the vegetation type, and disturbance level. For

162 vegetation type we used 4 categories: grassy steppe, shrub-steppe, shrubland, and wet-meadow.

163 Disturbance level was visually categorized in low (no clear sign of disturbance), intermediate

164 (low percentage of bare soil, few signs of herbivore damage to soil and vegetation and few

165 herbivore feces), and high (high percentage of bare soil, signs of soil disturbance due to grazing

166 or human activities, presence of species common in degraded areas, top soil removed, and

167 herbivore feces). All sampling sites were areas used for extensive livestock production with a

168 number of samples for each habitat type of: $n=26$ for grassy steppes; $n=38$ for shrub-steppes; $n$

$169=8$ for shrublands; and $\mathrm{n}=2$ for wet-meadows. Elevation ranged from 705 to $1240 \mathrm{~m}$ asl (Sup

170 Mat). Field work was approved by the National Park Administration (project number: 1526).

171 Analyses

172 To assess the effects of road verges on the density of B. tectorum in surrounding environments,

173 we fitted a generalized mixed effects model with Poisson distribution (Supplementary material).

174 Our response variable was the density of $B$. tectorum per $1 \mathrm{~m}^{2}$ plot in the surrounding

175 environments and the explanatory variable the density of B. tectorum in road verges. We

176 included co-variables to assess the influence of other potential variables affecting the results. For

177 this we included the distance (in meters) from the road verge, the level of disturbance and

178 vegetation type of the environment. The quantitative co-variables were centred and standardized

179 to make their coefficients comparable and to ease computational estimations. Following our

180 hierarchical sampling design, we used Road and Sampling Transect as nested random effects.

181 We considered intermediate disturbance levels and shrubland vegetation as reference group and

182 included an interaction term between level of disturbance and the average density of B. tectorum

183 in the road verges. All analyses were performed in R (R Core Team, 2016). Due to the spatial

184 nature of our data, we checked spatial autocorrelation by constructing a correlogram, using the

185 function spline.correlog( ) from ncf package (Bjornstad, 2009). After fitting the model that

186 included the spatial correlation term, we checked for spatial autocorrelation in the normalized

187 model's residuals using the acf( ) function. The final model, selected by the lowest AIC, was a

188 linear model with an interaction term between the density of B. tectorum in road verges and the

189 level of disturbance on the surrounding environment. Models fitting was performed using the

$190 \operatorname{gamm}($ ) function from mgcv package (Wood, 2011). 


\section{Results}

192 We found that the density of B. tectorum in road verges interacted with the disturbance in the 193 surrounding environment to determine its density in these latter habitats (Table 1). When the 194 contiguous environment was more conserved (i.e., lower levels of disturbance), the influence of 195 road verges on the density of $B$. tectorum inside the surrounding environment was high. Instead, 196 when this environment was moderate or highly disturbed the density of B. tectorum in these 197 areas did not depend on road verges densities. This result shows that in environments with low 198 disturbance levels, the density of $B$. tectorum increases as their density in road verges increases.

199 We also found that $B$. tectorum density decreases when we moved away from road verges towards the interior of surrounding environment (Table 1). This negative effect of distance from road verges on $B$. tectorum density showed an exponential decay of density when distance

202 increases, at a rate of 0.9 plants per meter (Fig. 2).

203 Results from the model fit confirmed the observations and raw data that shrub-steppes, grassy 204 steppes and shrublands showed similar B. tectorum densities and higher than wet-meadows

205 (Table 1; Fig. 3a). For instance, the estimated density of B. tectorum for shrub-steppes was 8.41 206 plants $/ \mathrm{m}^{2}, 6.82$ plants $/ \mathrm{m}^{2}$ for grassy-steppes, 6.55 plants $/ \mathrm{m}^{2}$ for shrublands and 3.25 plants $/ \mathrm{m}^{2}$ for

207 wetlands. Results also show that intermediate and highly disturbed environments present higher

208 densities of B. tectorum than those areas with low disturbance (Table 1; Fig. 3b).

\section{Discussion}

210 Our results highlight the importance of road verges on $B$. tectorum invasion into the surrounding

211 native communities. This importance is higher in cases were natural habitats are better conserved

212 and decreases when those habitats are more deteriorated. Previous studies also show that

213 invasive species progressively spread from initial introduction areas as roadsides (Tyser \&

214 Worley, 1992; Gelbard \& Belnap, 2003). Roads may be acting in Patagonia as conduits for the

215 spread of B. tectorum seeds as in the USA (Gelbard \& Belnap, 2003), where road maintenance

216 and vehicles contribute to human aided dispersal of invasive species seeds at short and

217 intermediate distances (Rauschert, Mortensen \& Bloser, 2017; Rew et al., 2018). However, their

218 importance depends on disturbance level. We found that density of $B$. tectorum in road verges is

219 more important in determining B. tectorum invasion in the surrounding habitats at low levels of

220 disturbance. However, when disturbance is high, the propagule source may be explained by self- 
221 maintaining $B$. tectorum populations where propagule source is not the road verge but the

222 populations themselves. However, our data are robust showing that effects of roads and

223 disturbance are not independent nor additive. Instead, the combined effects among these global

224 change drivers affect $B$. tectorum invasion in north-western Patagonia.

225 We found a similar B. tectorum density in steppes, shrub-steppes and shrublands in the native

226 environments adjacent to the roads which highlights its adaptability and capacity to invade

227 multiple ecosystems in Patagonia. B. tectorum germination, seedling and root development is

228 very fast in USA (Hulbert, 1955) what probably favours its presence in a constantly human-

229 modified area as roads verges and its success in invading close surrounding ecosystems. Our

230 result contrasts a previous study carried out in the same region that showed that steppes were the

231 most invaded habitat types (Speziale, Lambertucci \& Ezcurra, 2014). This could represent a

232 change in the invasion pattern with time. However, this previous study was conducted in areas as

233 little disturbed as possible (further away from roads), avoiding wet-meadows, and did not

234 separate steppes from shrub-steppes. The special case of wet-meadows probably represents a

235 niche outside $B$. tectorum ecological needs given that these edaphic community soils are

236 normally wetter than this species requirements and with high vegetation cover (Utrilla, Brizuela

237 \& Cibils, 2005), being probably environments where B. tectorum cannot outcompete native

238 vegetation.

239 The decline we found in the density of $B$. tectorum with distance from roads for all habitat types

240 evidences the importance of roads during the first stages of the invasion. At the same time, it

241 points at a greater competitive ability of native species, differences in disturbance at lower scale

242 than we measured or in native species composition, and/or at a lack of $B$. tectorum propagules

243 which have probably not reached the interior yet. Competitive ability and seed dispersal at

244 medium distance often account for invasion success (Brandt \& Rickard, 1994). Well conserved

245 local communities might be dominated by competitive species that are able to outcompete $B$.

246 tectorum in areas with low levels of disturbance (Davis, Grime \& Thompson, 2000; Fridley et

247 al., 2007). However, we found B. tectorum close to the road in all the habitats, with diverse

248 disturbance level, and a decline in density as we move away from them. Despite we selected

249 homogenous habitats it is possible that there were differences within plots in disturbance or

250 community's composition that we did not measure. Additionally, dispersal ability could explain 
251 the decreased density further away from roads. B. tectorum can disperse only one or two metres

252 without the aid of a vector. Its short dispersal ability could be compensated if the presence of

253 cattle would have aid the dispersal of propagules given their adaptations to epizoochory (Hulbert,

254 1955; Mack, 1981). Accurate measures of dispersal distance through wind and cattle vectors are

255 not available. This remains to be tested as no study has analysed B. tectorum dispersal and/or

256 competitive ability with native species, nor herbivory and seed predation in Patagonia.

257 Alternative, B. tectorum may be just ending a latency period given its relatively short time since

258 its first introduction in Patagonia (Biganzoli, Larsen \& Rolhauser, 2013; Speziale, Lambertucci

259 \& Ezcurra, 2014) what could explain its progressive increase in density within the native

260 surroundings.

\section{Conclusions}

262 Synergies among global change drivers can impact native environments favouring the invasion

263 of B. tectorum. Not only habitat type is important to resist B. tectorum invasion. Within habitats

264 susceptible to invasion (all but wet-meadows) road verges influenced the density of B. tectorum

265 in the surrounding habitat but its importance changed with the habitat disturbance level. This

266 synergy among global drivers needs to be taken into account to develop accurate management

267 tools (Didham et al., 2005). According to it, minimizing road construction and improvement of

268 existing ones, as well as designing road verges vegetation programs to quickly detect and prevent

269 invasions are important recommendations for the sustainable management of ecosystems (Tyser

270 \& Worley, 1992; Gelbard \& Belnap, 2003). Also, our results stem new recommendations. Given

271 the low invasion of habitats with low sign of degradation, the common-sense recommendation

272 would be to keep this good habitat conservation. However, it is important to design and

273 implement both strategies at a time: B. tectorum controls in road verges and avoiding high

274 disturbances within the ecosystems. Additionally, when habitat disturbance level is already high,

275 restoration of the ecosystem would be needed in addition to road verge management. This is

276 important both to reduce potential B. tectorum invasion impacts but also from a productive point

277 of view which seeks good pastures for the domestic animals. 
279 References

280 Biganzoli F., Larsen C., Rolhauser AG. 2013. Range expansion and potential distribution of the 281 invasive grass Bromus tectorum in southern South America on the base of herbarium records. 282 Journal of Arid Environments 97:230-236.

283 Bjornstad ON. 2009. ncf: spatial nonparametric covariance functions. R package-version 1.1-3. 284 http://cran. r-project. org/.

285 Bradford JB., Lauenroth WK. 2006. Controls over invasion of Bromus tectorum: the importance 286 of climate, soil, disturbance and seed availability. Journal of Vegetation Science 17:693$287 \quad 704$.

288 Bradley BA. 2009. Regional analysis of the impacts of climate change on cheatgrass invasion shows potential risk and opportunity. Global Change Biology 15:196-208.

Brandt CA., Rickard WH. 1994. Alien taxa in the North American shrub-steppe four decades 291 after cessation of livestock grazing and cultivation agriculture. Biological conservation 68:95-105.

Brook B., Sodhi N., Bradshaw C. 2008. Synergies among extinction drivers under global change. Trends in Ecology \& Evolution 23:453-460. DOI: 10.1016/j.tree.2008.03.011.

Chapin III FS., Zavaleta ES., Eviner VT., Naylor RL., Vitousek PM., Reynolds HL., Hooper DU., Lavorel S., Sala OE., Hobbie SE., others 2000. Consequences of changing biodiversity. Nature 405:234-242.

Christen DC., Matlack GR. 2009. The habitat and conduit functions of roads in the spread of three invasive plant species. Biological Invasions 11:453-465.

Dainese M., Aikio S., Hulme PE., Bertolli A., Prosser F., Marini L. 2017. Human disturbance and upward expansion of plants in a warming climate. Nature Climate Change 7:577. 
302 D'Antonio CM., Vitousek PM. 1992. Biological invasions by exotic grasses, the grass/fire cycle, 303 and global change. Annual review of ecology and systematics 23:63-87.

304 Davis MA., Grime JP., Thompson K. 2000. Fluctuating resources in plant communities: a 305 general theory of invasibility. Journal of Ecology 88:528-534.

306 Didham R., Tylianakis J., Gemmell N., Rand T., Ewers R. 2007. Interactive effects of habitat

307 modification and species invasion on native species decline. Trends in Ecology \&

308 Evolution 22:489-496. DOI: 10.1016/j.tree.2007.07.001.

309 Didham RK., Tylianakis JM., Hutchison MA., Ewers RM., Gemmell NJ. 2005. Are invasive 310 species the drivers of ecological change? Trends in Ecology \& Evolution 20:470-474.

311 Dukes JS., Mooney HA. 1999. Does global change increase the success of biological invaders?

312 Trends in Ecology \& Evolution 14:135-139.

313 Fridley JD., Stachowicz JJ., Naeem S., Sax DF., Seabloom EW., Smith MD., Stohlgren TJ.,

314 Tilman D., Holle BV. 2007. The invasion paradox: reconciling pattern and process in

$315 \quad$ species invasions. Ecology 88:3-17. DOI: $10.1890 / 0012-$

$316 \quad 9658(2007) 88[3:$ TIPRPA $] 2.0 . \mathrm{CO} ; 2$.

317 Forman RT. 2003. Road ecology: science and solutions. Island Press.

318 Forman RT., Alexander LE. 1998. Roads and their major ecological effects. Annual review of 319 ecology and systematics 29:207-231.

320 Frenkel RE. 1977. Ruderal vegetation along some California roadsides. Univ of California $321 \quad$ Press.

322 Gelbard JL., Belnap J. 2003. Roads as conduits for exotic plant invasions in a semiarid 323 landscape. Conservation Biology 17:420-432. DOI: 10.1046/j.1523-1739.2003.01408.x. 
324 Hulbert LC. 1955. Ecological studies of Bromus tectorum and other annual bromegrasses. 325 Ecological Monographs:181-213.

326 Ibisch PL., Hoffmann MT., Kreft S., Pe’er G., Kati V., Biber-Freudenberger L., DellaSala DA.,

327

328

329

330

331

332

333

334

335

336

337

338

339

340

341

342

343

344

345

346

Vale MM., Hobson PR., Selva N. 2016. A global map of roadless areas and their conservation status. Science 354:1423-1427. DOI: 10.1126/science.aaf7166.

Lavin M., Brummer TJ., Quire R., Maxwell BD., Rew LJ. 2013. Physical disturbance shapes vascular plant diversity more profoundly than fire in the sagebrush steppe of southeastern Idaho, USA. Ecology and evolution 3:1626-1641.

Lembrechts JJ., Pauchard A., Lenoir J., Nuñez MA., Geron C., Ven A., Bravo-Monasterio P., Teneb E., Nijs I., Milbau A. 2016. Disturbance is the key to plant invasions in cold environments. Proceedings of the National Academy of Sciences 113:14061-14066.

Lowe PN., Lauenroth WK., Burke IC. 2003. Effects of nitrogen availability on competition between Bromus tectorum and Bouteloua gracilis. Plant Ecology 167:247-254.

Mack RN. 1981. Invasion of $<\mathrm{i}>$ Bromus tectorum $</ \mathrm{i}>$ L. into Western North America: An ecological chronicle. Agro-ecosystems 7:145-165.

Mack RN. 1986. Alien plant invasion into the Intermountain West: a case history. In: Ecology of biological invasions of North America and Hawaii. Springer, 191-213.

Mack RN., Pyke DA. 1983. The demography of Bromus tectorum: variation in time and space. The Journal of Ecology:69-93.

Ottar N. Bjornstad (2016). ncf: Spatial Nonparametric Covariance Functions. R package version 1.1-7. https://CRAN.R-project.org/package=ncf.

Rauschert ES., Mortensen DA., Bloser SM. 2017. Human-mediated dispersal via rural road maintenance can move invasive propagules. Biological Invasions 19:2047-2058. 
347 R Core Team. 2016. R: A language and environment for statistical computing. Vienna, Austria:

$348 \quad$ R Foundation for Statistical Computing.

349 Rew LJ., Brummer TJ., Pollnac FW., Larson CD., Taylor KT., Taper ML., Fleming JD., Balbach

350 HE. 2018. Hitching a ride: Seed accrual rates on different types of vehicles. Journal of

351 environmental management 206:547-555.

352 Rice KJ., Black RA., Radamaker G., Evans RD. 1992. Photosynthesis, growth, and biomass

353 allocation in habitat ecotypes of cheatgrass (Bromus tectorum). Functional Ecology:32-

$354 \quad 40$.

355 Rickard WH., Vaughan BE. 1988. Plant community characteristics and responses. Shrub-steppe:

356 balance and change in a semi-arid terrestrial ecosystem:109-179.

357 Sala OE., Chapin III FS., Armesto JJ., Berlow E., Bloomfield J., Dirzo R., Huber-Sanwald E.,

358 Huenneke LF., Jackson RB., Kinzig A., others. 2000. Global biodiversity scenarios for 359 the year 2100. Science 287:1770-1774.

360 Spellerberg IAN. 1998. Ecological effects of roads and traffic: a literature review. Global $361 \quad$ Ecology and Biogeography 7:317-333.

362 Speziale KL., Lambertucci SA., Ezcurra C. 2014. Bromus tectorum invasion in South America:

363 Patagonia under threat? Weed Research 54:70-77.

364 Strano E., Viana MP., Sorichetta A., Tatem AJ. 2018. Mapping road network communities for 365 guiding disease surveillance and control strategies. Scientific Reports 8:4744. DOI:

$366 \quad 10.1038 / \mathrm{s} 41598-018-22969-4$.

367 Taylor K., Brummer T., Taper ML., Wing A., Rew LJ. 2012. Human-mediated long-distance

368 dispersal: an empirical evaluation of seed dispersal by vehicles. Diversity and

369 Distributions 18:942-951. DOI: 10.1111/j.1472-4642.2012.00926.x. 
370 Tilman D. 1997. Community invasibility, recruitment limitation, and grassland biodiversity. $371 \quad$ Ecology 78:81-92.

372 Trombulak SC., Frissell CA. 2000. Review of ecological effects of roads on terrestrial and 373 aquatic communities. Conservation biology 14:18-30.

374 Tyser RW., Worley CA. 1992. Alien flora in grasslands adjacent to road and trail corridors in 375 Glacier National Park, Montana (USA). Conservation Biology 6:253-262.

376 Utrilla V., Brizuela M., Cibils A. 2005. Riparian habitats (mallines) of Patagonia A key grazing resource for sustainable sheep-farming operations. DOI: 10.5367/0000000053295088.

378 Veblen TT., Mermoz M., Martin C., Kitzberger T. 1992. Ecological impacts of introduced animals in Nahuel Huapi National Park, Argentina. Conservation Biology 6:71-83.

380 Vitousek PM., D’Antonio CM., Loope LL., Westbrooks R., others. 1996. Biological invasions as 381 global environmental change. American Scientist 84:468-478.

382 Von der Lippe M., Kowarik I. 2007. Long-Distance Dispersal of Plants by Vehicles as a Driver 383 of Plant Invasions. Conservation Biology 21:986-996.

384 Wood SN. 2011. Fast stable restricted maximum likelihood and marginal likelihood estimation 385 of semiparametric generalized linear models. Journal of the Royal Statistical Society: $386 \quad$ Series B (Statistical Methodology) 73:3-36. 


\section{Figure 1}

Study area in northwestern Patagonia

Study was conducted along roads of Neuquén and Rio Negro provinces in Argentina. Red dots show sampling plot location. Map data Google, SIO, NOAA, U.S. Navy, GEBCO, US Dept of State Geographer, Image Landsat/Copernicus.

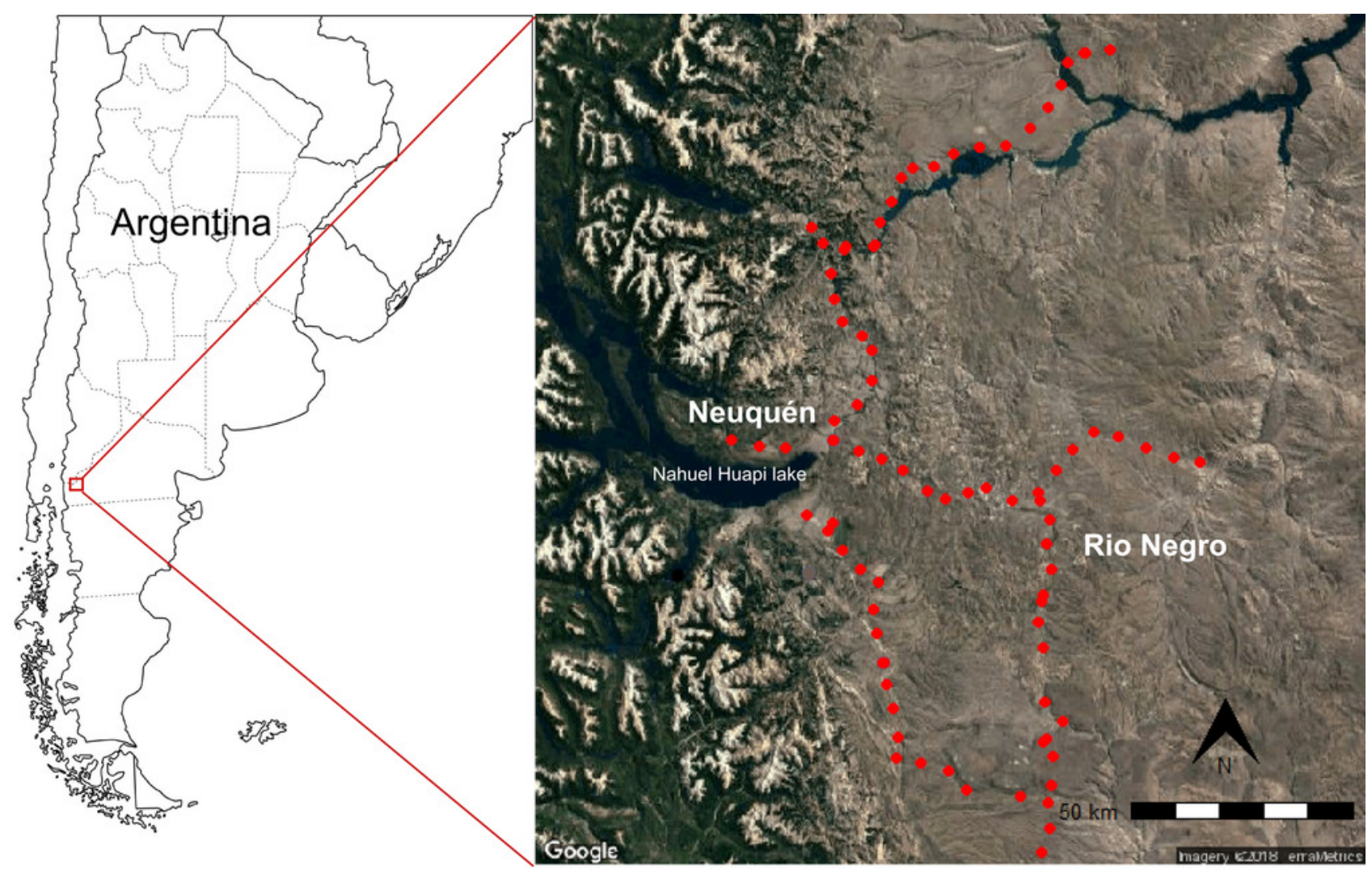




\section{Figure 2}

Exponential decay of $B$. tectorum density with distance from road verges.

The black dots represent the mean observed values of density at each measured distance, and the bars are the standard errors. The solid line is the expected decay obtained from model fit, and dashed lines are the $95 \%$ confident intervals. 


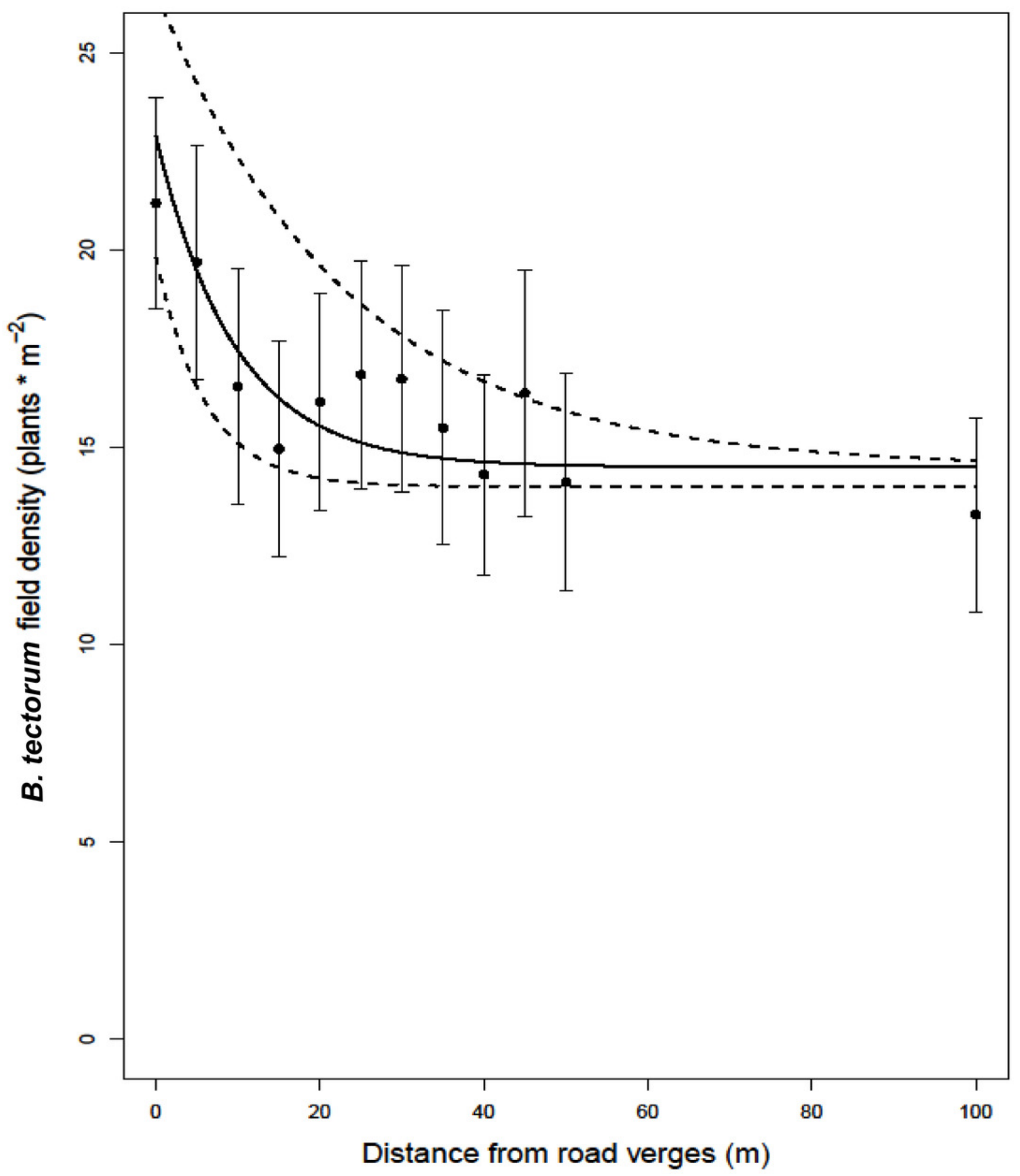


Figure 3

Observed values of B.tectorum density in natural environments

(a) Vegetation type and (b) disturbance level measured in the natural environment. 


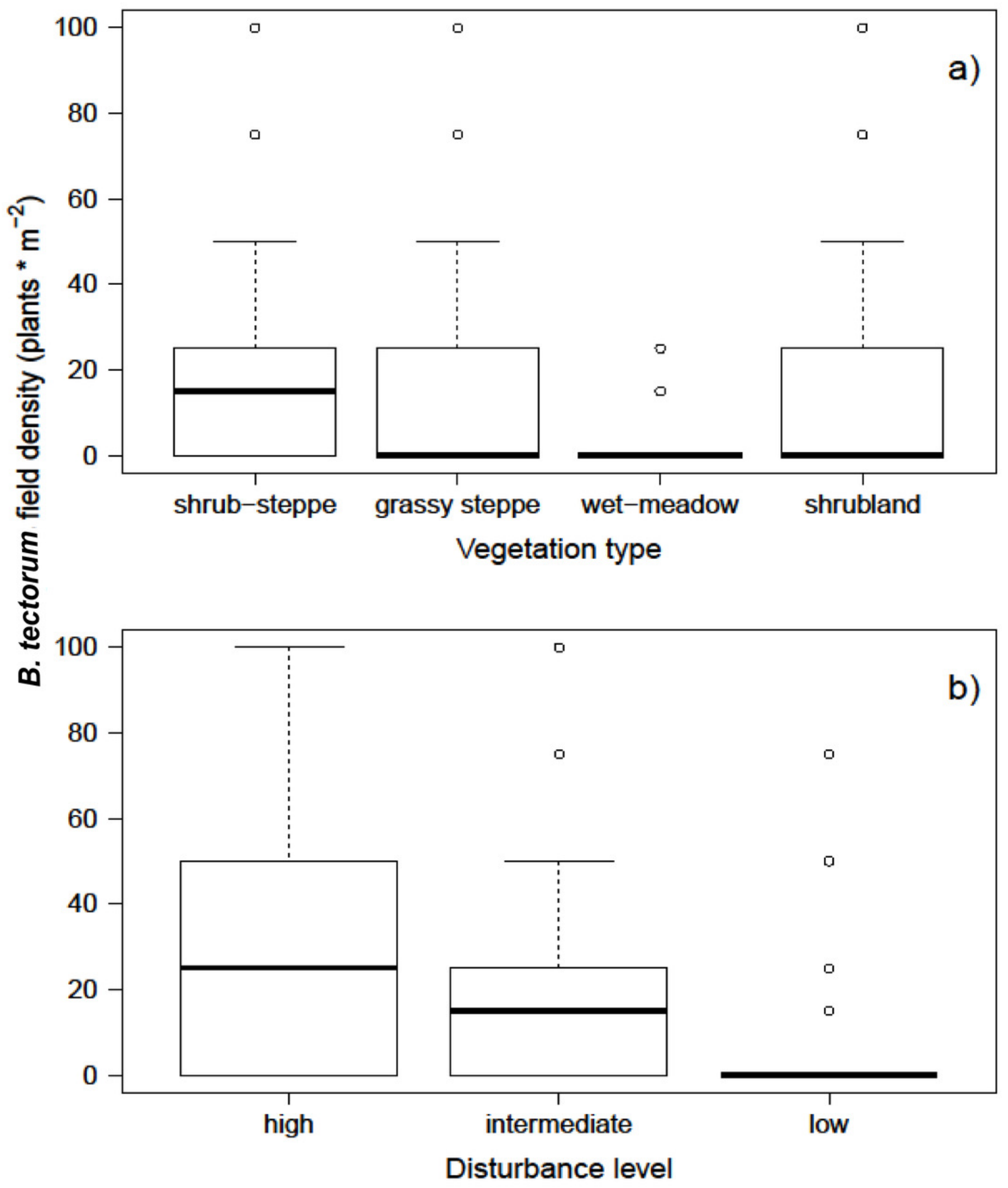




\section{Table $\mathbf{1}$ (on next page)}

Model's fixed effects coefficients

Expected values in log scale, Standard Errors (SE), Degrees of Freedom (DF), t-values, 95\% Confidence Intervals $(95 \% \mathrm{Cl})$, and $p$-values for the model's fixed effects. $\beta_{0}$ is the model's intercept, which includes Intermediate disturbance level and shrubland vegetation as reference group. $\beta_{1}$ and $\beta_{2}$ are the regression coefficients for high and low levels of field disturbance respectively. $\beta_{3}$ represents the effect of $B$. tectorum density (plants* ${ }^{2}$ )at road verges on field density. $\beta_{4}, \beta_{5}$ and $\beta_{6}$ show the effects of grassland, wetland and shrubland vegetation on $B$. tectorum density in the field, respectively. $\beta_{7}$ represents the effect of distance from verges (in meters) on the density of $B$. tectorum in the field. $\beta_{8}$ and $\beta_{9}$ are the interaction terms between $B$. tectorum density on road verges and the level of disturbance of the field. Statistically significant $p$-values are marked with *, and $B t$ is an abbreviation for B. tectorum. 


\section{Table}

\begin{tabular}{lccccccc}
\hline & & & & & \multicolumn{2}{c}{$95 \%$ CI } & \\
\cline { 7 - 8 } Parameters (log scale) & Estimated & SE & DF & t-value & Lower & Upper & p-value \\
\hline$\beta_{0}:$ Intercept & 2.13 & 0.19 & 859 & 11.39 & 1.76 & 2.49 & $0.001^{*}$ \\
$\beta_{1}:$ High disturbance level & 0.31 & 0.29 & 859 & 1.07 & -0.27 & 0.90 & 0.288 \\
$\beta_{2}:$ Low disturbance level & -1.15 & 0.43 & 859 & -2.66 & -2.01 & -0.29 & $0.010^{*}$ \\
$\beta_{3}:$ Bt density in verge & 1.01 & 0.14 & 859 & 7.46 & 0.74 & 1.28 & $0.001^{*}$ \\
$\beta_{4}:$ Grassland & -0.21 & 0.28 & 859 & -0.75 & -0.76 & 0.34 & 0.454 \\
$\beta_{5}:$ Wetland & -0.95 & 0.10 & 859 & -2.28 & -2.07 & -1.57 & $0.002^{*}$ \\
$\beta_{6}:$ Shrubland & -0.25 & 0.46 & 859 & -0.54 & -1.16 & 0.66 & 0.591 \\
$\beta_{7}:$ Distance from verge & -0.10 & 0.03 & 859 & -3.31 & -0.17 & -0.04 & $0.001^{*}$ \\
$\beta_{8}:$ Bt verges * High disturb & 0.04 & 0.03 & 859 & 1.29 & -0.02 & 0.10 & 0.201 \\
$\beta_{9}:$ Bt verges * Low disturb & 1.59 & 0.11 & 859 & 14.02 & 1.37 & 1.81 & $0.001^{*}$ \\
\hline
\end{tabular}

